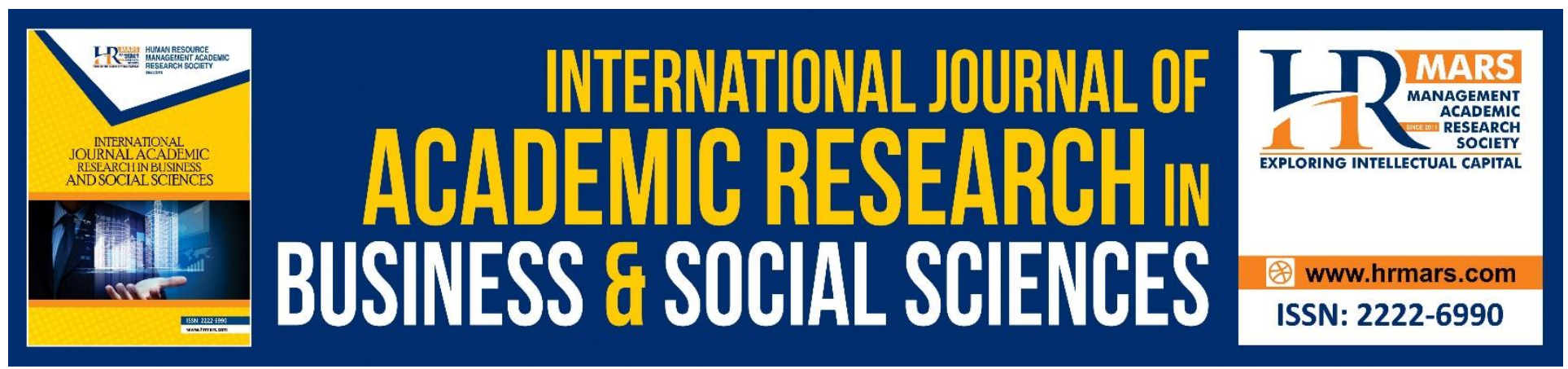

\title{
Assessment of Urbanization and Urban Sprawl Analysis through Remote Sensing and GIS: A Case Study of Faisalabad, Punjab Pakistan
}

\section{Qurratulain Safder, Umair Babar}

To Link this Article: http://dx.doi.org/10.6007/IJARBSS/v9-i4/5811

DOI: $10.6007 /$ IJARBSS/v9-i4/5811

Received: 20 Feb 2019, Revised: 1 March 2019, Accepted: 25 March 2019

Published Online: 13 April 2019

In-Text Citation: (Safder, 2019)

To Cite this Article: Safder, Q. (2019). Assessment of Urbanisation and Urban Sprawl Analysis through Remote Sensing and Gis: A Case Study of Faisalabad, Punjab Pakistan. International Journal of Academic Research Business and Social Sciences, 9(4), 16-36.

Copyright: (C) 2019 The Author(s)

Published by Human Resource Management Academic Research Society (www.hrmars.com)

This article is published under the Creative Commons Attribution (CC BY 4.0) license. Anyone may reproduce, distribute, translate and create derivative works of this article (for both commercial and non-commercial purposes), subject to full attribution to the original publication and authors. The full terms of this license may be seen

at: $\underline{\text { http://creativecommons.org/licences/by/4.0/legalcode }}$

Vol. 9, No. 4, 2019, Pg. 16 - 36

Full Terms \& Conditions of access and use can be found at http://hrmars.com/index.php/pages/detail/publication-ethics 


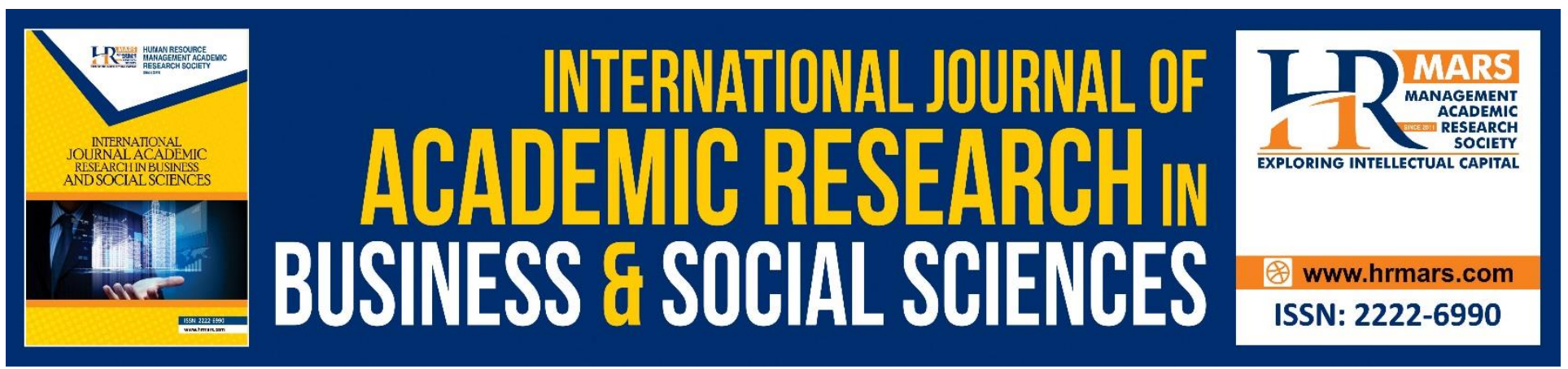

\title{
Assessment of Urbanization and Urban Sprawl Analysis through Remote Sensing and GIS: A Case Study of Faisalabad, Punjab Pakistan
}

\author{
Qurratulain Safder ${ }^{\mathrm{a}}$, Umair Babar ${ }^{\mathrm{b}}$ \\ a Punjab University College of Information Technology, Lahore, Pakistan \\ ${ }^{b}$ Lecturer, Faculty of CS, PUCIT, Lahore, Pakistan \\ Email: qurratulainsafder@gmail.com,Umair.babar@pucit.edu.pk
}

\begin{abstract}
The Research work tends to explore the rapid sprawl in Faisalabad, Punjab Pakistan. Land constitutes of vital and influential, having a high rank of great significance. Contributing in the socio-economy of Pakistan. This study analyzes spatial restructuring of land use patterns using spatial techniques, GIS \& Remote sensing. In mega cities and resident's consumption rate led environmental degradation. Land deformation has been witnessed without any policy intervention. Land Use Land Use Land cover data is highly acknowledged for land resources management. The total areal change due to massive migration from rural to urban has legitimated various land deforming issues for the land managers and planners (i.e. unplanned growth, poor environment). In Pakistan, Karachi and Lahore are two major cities known as mega cities and now Faisalabad amongst the cities, but to define the change multiple geo-spatial techniques and temporal analysis will be performed. To cope up the growthrelated issues it is necessary to detect the drastic change as it's an ongoing process. Land change and deformation can be mapped, by using remote sensing data and GIS techniques along with several statistical measures. This study examines the trend of change in land pattern in spatial and temporal dimensions. The result will indicate the tendency of land deterioration.
\end{abstract}

Keywords: Remote Sensing and GIS, Urban Sprawl, Urbanization, Land Use/Land Cover, Urbanization, Change detection, Spatial Pattern.

\section{Introduction}

The research mainly analyzes spatial pattern analysis Urban sprawl and rapid growth refer to the process of increasing concentration of population within a city. The world had been changed, but the most significant change is increased population in urban areas. It starts from a point and then it spreads in multiple directions. The phenomena of sprawl of urban areas engulfed the other land and 
deform the land horizontally dispersedly so currently the phenomena are under consideration of establishments, policymakers and authorities because of this issue directly and indirectly associated with transportation, environment, pollution, employment, land degradation, water sustainability, planning. As Pakistan is among those countries whom economy relies upon the agricultural land Almost $25 \%$ of GDP Gross Domestic Product inclusively append to Pakistan economy. People of Pakistan relies on agriculture not only rural areas are being fed by agriculture but the city's economy also rely on agriculture and urban land swallowing the rural land day by day and it is continuous phenomena so this study mainly focusing the land pattern using geospatial tools and techniques to map and measure the transformation of land over the last 30 years. How the land has deformed and what is the outcome of other land covers and land usage. The land management authorities

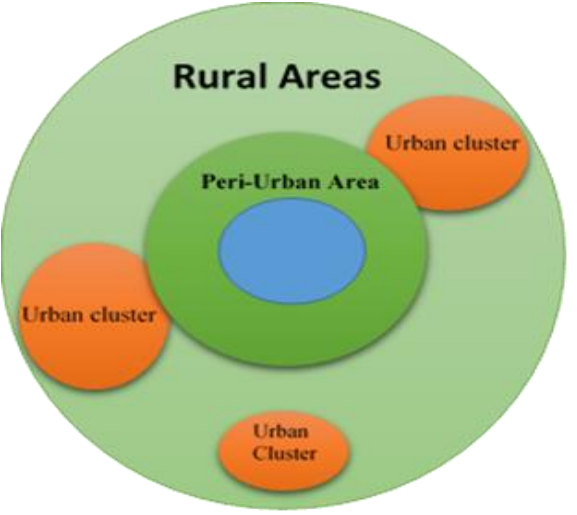
need updated statistics and figures to make policies and planning one of extensively method to measure the sprawl and manage the spatial extent by using Remote sensing and GIS as a tool so the outcome of the research fed quantitively \& qualitatively currently, there is no updated work upon urban sprawl outdated Analysis available but currently using advance RSGIS work is required to cope up and stipulate the worldwide confronted issue. To ensure the sustainability of agriculture land the sprawl management plays a vital role to cope up the future requirements. Rapid the urban process leads troublesome threatens not only the environment but also living style water consumption, land transformation, crop pattern, habitat, increasing the public services costs and this overall new dimension, which is hazardous to living beings. The shift of proportion, which is getting heavier on cities side and creating the need to measure the level of sprawl in the area. Urbanization affecting the communities in recent years drastically so for urban planning it is compulsory and the necessity to know the growth trend because of every place trend varies from one another so as concerned study area from other Pakistani cities. It became important to timely monitor the change in LULC (Land cover land use). So, fulfilling the necessity, by studying such phenomenon for appropriate management.

With the help of satellite imagery and geospatial techniques (Maximum likelihood classification), main emphasis and concentration to determine land change over the past two decades. For land configuration, ML technique resulted in four land covers, distinctively for each decade. Valuation and quantitative calculation of each selected year $(1999,2010$ \& 2019) has performed. Post accuracy analysis has been made for the assessment of land declination. The transformation of land cover using a pivot table, Error matrix, Change matrix and by graphical representation (Clustered column Line, pie chart, Area chart) Fig:6-9

The research mainly aims to produce an outcome about the land change percentage/ratio with the help of LULC map-to-map comparison with the amalgamation of error matrix, user accuracy and accuracy and pivot tables and error proportion. The result dictates the land transformation from 1999 to present indicated by the Faisalabad maps. Foremost objective and consideration stipulate to land 
transformation over decades (1999- 2019) it is important to study such phenomenon for planning. Urban growth can be, measured, modelled and mapped by using remote sensing data and GIS techniques along with several statistical measures. The application of new techniques has created opportunities to analyze urban growth process. Advancement creates more ways to manipulate the mechanism i.e. Transformation of landscape etc. The development in the city has changed the pattern of land. Due to an increasing proportion of urbanization and the sprawl need to acknowledge the threat to agriculture sector, crop pattern shiftiness, water consumption and more towards the air we use to survive. Urbanization is the proportion of population or people move from rural areas to urban areas i.e. if 40:60, 40 percent people live into the rural side areas whereas 60 percentage in urban side, urbanization refers to more tendency towards urban areas (cities \& towns). On the other hand, another important aspect of the Research is sprawl which is people living away from the central main hub for example low-density sides, Transport dependent communities. The urban sprawl usually generalized as suburbanization. The term land cover is different from land use and the Environmental managers and the public and private planners have realized both vast fields to map the trend of urbanization in Pakistan. In land use how the landscape is being used by the people for the people, physically how land is utilized for development or manufacturing or industrial purpose on the other hand land cover is a covered area by some vegetation or some crops.

The growth the pattern varies from one place to another and to measure so one cannot measure the static state for this one needs to go through at multiple times so multi temporal images were taken for the analysis to view the land in different time periods and impact examination of one variable (Urban) to other variables which are Vegetation bare land soil and water. The spatial change can be analyzed when we compare two or more maps and generate an image to image comparison of how the transformation trend was and now the is the trend state.

In this research the most prominent aim is to enumerate and calculate the change in percentage Table. The spatial reflectance, radiometric sense ability \& spectral resolution feed the temporal analysis and helps to measure and detect \& quantify the change. For each land class spectral reflectance calculated (Digital no) what Satellite capture and stores (the remotely sensed data) and then the result interpreted and evaluation of analysis with the help GIS and its geospatial techniques made possible. Moreover, the Maximum likelihood is human interactive to interpret the coarse spectral signal so unsupervised is less accepted compare to $\mathrm{ML}$ technique as the user interaction involved the human interactive techniques utilize human familiarity with the zone (Faisalabad). Land cover and land use change is an international phenomenon. The change in land (urban Sprawl) is increasing at an alarming rate leading to global warming and Pakistan is one of those countries. Cities are the clusters of population agglomerations. It became important to timely monitor the change in LULC (Land cover land use). To understand change, temporal analysis plays a vital role to compare past trend of land change. For this purpose, satellite images between different periods assessed, compared statistically. In addition, it is clearly indicated that urban sprawl and built-up area cause land loss. The satellite data is a response generated by the reflectance of each wave to the land cover features and the features are further classified as 
INTERNATIONAL JOURNAL OF ACADEMIC RESEARCH IN BUSINESS AND SOCIAL SCIENCES Vol. 9, No. 4, April, 2019, E-ISSN: 2222-6990 @ 2019 HRMARS

\begin{tabular}{|l|l|l|}
\hline Category-1 & Category-2 & Category-3 \\
\hline $\begin{array}{l}\text { Urban development } \\
\text { /Built-up }\end{array}$ & $\begin{array}{l}\text { High/low- } \\
\text { density }\end{array}$ & $\begin{array}{l}\text { Commercial, Residential, } \\
\text { industrial, } \\
\text { Noncommercial, } \\
\text { Recreational (Parks) }\end{array}$ \\
\hline Vegetation & $\begin{array}{l}\text { High/low- } \\
\text { density }\end{array}$ & $\begin{array}{l}\text { Agriculture/Bare/Crops } \\
\text { Water bodies } \\
\text { Table 1: Land Classes }\end{array}$ \\
\hline Water & Bare Soil & Shrubs, bushes \\
\hline Bare land & \multicolumn{2}{|l}{}
\end{tabular}

Paul Knox-an urban planner, elaborate that the planning emerges out of a no of crises and how people respond to them

- Crises related to Health

- Crises related to Social network

- And Other Crises

Planning tries to mitigate the adverse elements of capitalism, but also makes capitalism viable over the long term. The dramatic change is directly associated with human, geophysical, rapid economic growth, climate and proximity factors. The aim of the analysis is to find out the pattern of land deformation from past year to future time. To predict and examine methodically, the assessment, conservation, and the consequences of landscape dynamics. The pattern varies from one place to another and it is important to study such phenomenon for planning. Modification in land use and land cover can be mapped, modelled and measured by using remote sensing data and GIS techniques along with several statistical measures.

Most of the major cities of Pakistan are rapidly tends to industrialization and people have an inclination of rural to urban migration. The land use pattern changes drastically. The world population is shifting continuously from rural to urban. In 2008 half, the world population raised in urban areas and by 2050 it will 68\%. (UN, 16 May 2018). Urbanization - redistribution of population from the countryside to the city, therefore urbanization is measured as the percent of the population residing in an urban area.

\begin{tabular}{|l|l|l|l|l|l|}
\hline District Faisalabad Census 1998 to 2017 \\
\hline Census & Rural & Urban & Total & Rural ratio & $\begin{array}{l}\text { Urban } \\
\text { ratio }\end{array}$ \\
\hline 1998 & 435968 & 315007 & 750975 & 58.05 & 41.95 \\
\hline 2017 & 4113582 & 3760328 & 7873910 & 52.24 & 47.76 \\
\hline
\end{tabular}

Table 2: FSD Census 
The factor that determine urbanization in Faisalabad includes internal migration (Rural to urban), international migration and natural increase. Rural area migration release pressure to urban areas. Faisalabad is one of the cities in Pakistan, which is on 3rd no in most populous category and 2nd largest in the eastern province of Punjab and known as Manchester of Pakistan because of largest textile industrial zone. Faisalabad after Lahore famous for flavor and foods. The population and industrial growth ratio lead to shrinking the land leading to the emergence of planning. To measure and manage urban growth the main reason of land cover modification is significant to manage resources. LULC changes over years will be analyzed to depict how enforcing land use planning can affect the immensity and protecting land, however, should be the highest priority to sustain land in the study area.

\section{Project Overview Statement}

This Overview Statement is intended to outline the key strategies and directions set out to manage the City, which had been changed since 2000. Uncontrolled expansion has been facilitated by rapid industrialization and fast growth in communication and new economic opportunities mostly found in the surrounding regions of an urban Center. This sort of growth later takes different shapes in different directions. Urbanization takes place in most of the developing countries, the topography and environment have undergone considerable change in most of fast growing, and developing countries and unplanned growth requires urban planner's attention in the urban geography field, to be strategized and stabilized for better planning in the future. Faisalabad is a prominent city among the rapidly growing cities of Pakistan. It is expanding with the industrial growth, historically the planned city

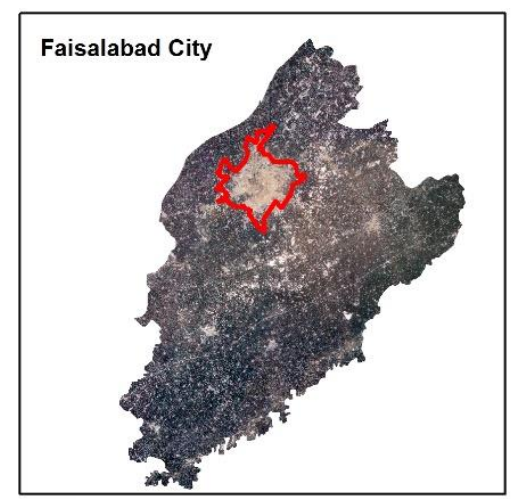

Figure 1: Faisalabad City within India. Faisalabad is among of those cities in Pakistan, which are more extensive than their local admin boundary. Now more than half of inhabitants of the world lives in urban areas progressively, to an increasing extent, highly dense cities. (Roser, 2018) so, there is a great need to draw the attention of policy makers upon uncontrolled expansion. Discussions regarding spatial management with GIS tools have dominated research in recent years and have much importance, especially in remote areas where hard to visit i.e. barren land, forest, restricted area. Here remote sensing plays a vital role in our research not only for local expansion, but widely as Global as well. 


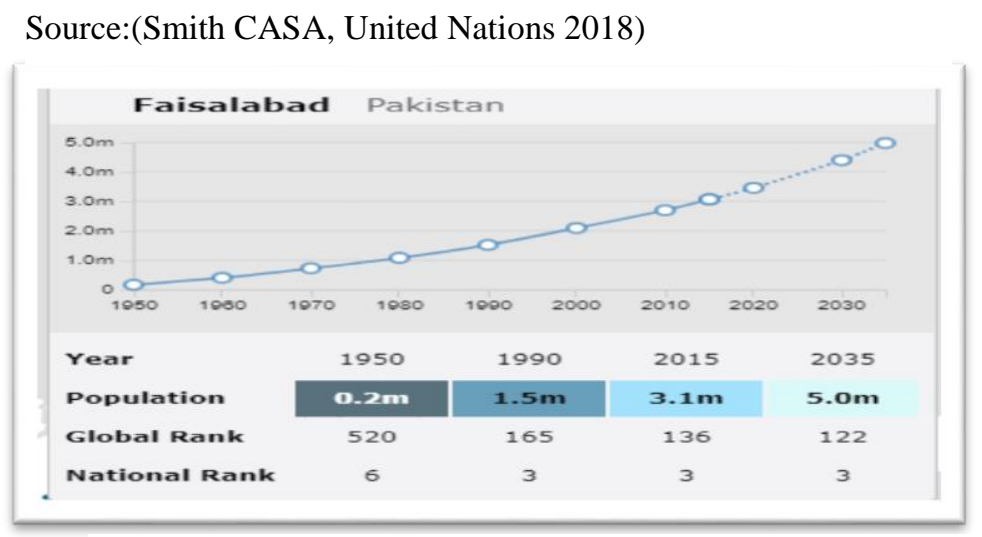

Figure 2: World City Populations 1950 - 2035

This Overview Statement is intended to outline the key strategies and directions set out to manage the City which had been changed since 2000. The Uncontrolled expansion has been facilitated by rapid Industrialization and fast growth in communication and new economic opportunities mostly found in the surrounding regions of an Urban Center. This kind of growth later takes different shapes in different directions. Specific objectives of the study:

\section{Research Questions}

$>$ What is the impact of development on agricultural land and other (Vegetation, Forestland, and Barren land)?

$>$ What are the Positive or negative consequences of urban growth?

$>$ How geospatial techniques can be helpful for land use planning?

$>$ What are the temporal land trends during the time span of the study?

$>$ To analyze agricultural land loss due to urbanization.

\section{Study Area}

Faisalabad is one of the densely inhabited and third main city among five major (Multan, Karachi, Lahore, Rawalpindi, Gujranwala) cities of Pakistan It is most planned city of the British Indian History. Faisalabad lies at $31.4504^{\circ} \mathrm{N}$ latitude; $73.1350^{\circ} \mathrm{E}$ longitude, consists of 6 Tehsils.

With the advancement and improvement in lifestyle of urban areas, people get attracted for employment foster the sprawl being an industrial zone the people get attracted and they tend to move from urban adjoining areas to urban area for prosperity, which plays a vigorous role in such undistributed spatial sprawl. To measure and manage urban growth the main reason of land cover modification is significant to manage resources. LULC changes over years will be analyzed to depict how enforcing land use planning can affect the immensity and protecting land, however, should be the highest priority to sustain land in the study area. 


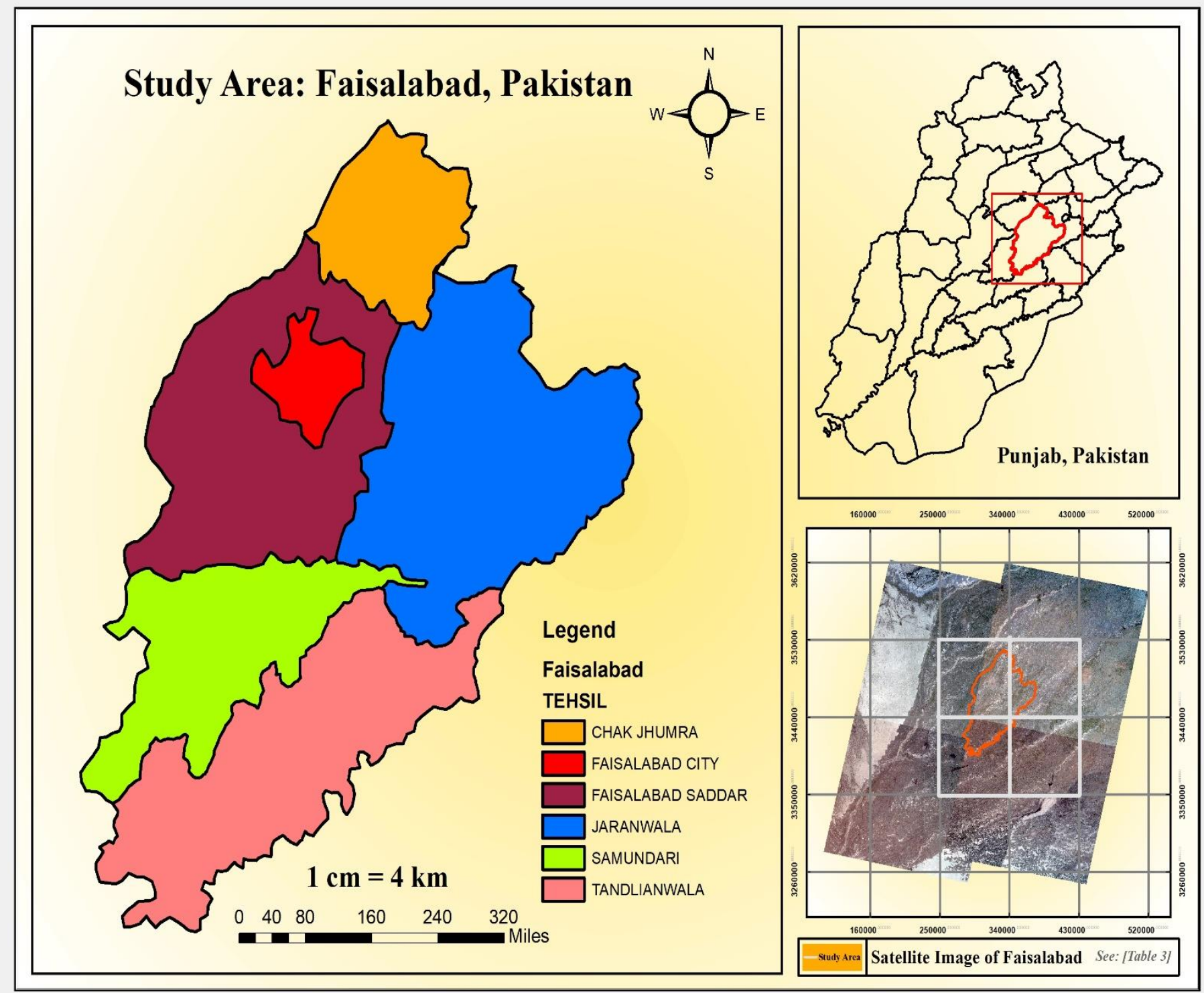

Figure 3: Study Area (Faisalabad)

\section{Workflow and Implications}

To achieve our task, we will take help of multiple tools that is ArcMap as a classification tool, ENVI for Seamless Mosaicking \& Excel Pivot tool for land change detection Research procedure is a vital part of the Assessment and analysis how the measures are performed and in which steps the aim has achieved. There are numeral of phases, intricate to perform the Landover analysis.

\section{Image Acquisition \& Processing}

To monitor the land dynamic changes, expansion, and identification of urbanization since 1990 ENVI, Erdas Imagine and top of all ArcGIS 10.5 Microsoft Word and Excel 2016 mainly have 
INTERNATIONAL JOURNAL OF ACADEMIC RESEARCH IN BUSINESS AND SOCIAL SCIENCES Vol. 9, No. 4, April, 2019, E-ISSN: 2222-6990 @ 2019 HRMARS

used for LULC mapping. For temporal analysis remotely sensed date is required to study the most populous and major city of Pakistan. As the present research based over a time span so Multi imagery is required to assess \& monitor the land over time interval. Almost with ten years' time interval 3 Satellite images has downloaded 1999-2010 \& from 2010 till now. Each image

Data Source: USGS Earth Explorer

\begin{tabular}{|l|l|l|l|l|l|}
\hline $\begin{array}{l}\text { Sr. } \\
\text { No }\end{array}$ & Years & $\begin{array}{l}\text { Satellite } \\
\text { images }\end{array}$ & Row/Path & $\begin{array}{l}\text { Bands } \\
\text { combination }\end{array}$ & Resolution \\
\hline 1. & 1999 & Landsat 4-5 & $\begin{array}{l}148 / 39,148 / 38,150 / 38, \\
150 / 39\end{array}$ & $7(5,4,2)$ & 30 \\
\hline 2. & 2010 & Landsat 4-5 & $\begin{array}{l}148 / 39,148 / 38,150 / 38, \\
150 / 39\end{array}$ & $7(5,4,2)$ & 30 \\
\hline 3. & 2019 & Sentinel & $\begin{array}{l}\text { Tile no: T43RBQ, T43RCQ, } \\
\text { T43SCR }\end{array}$ & $12(12,11,4)$ & 60 \\
\hline
\end{tabular}

Table 3: Landsat Datatype

consists of 7 spectral band and each band contains unique characteristic about land object with the help of stored Digital No Value (Reflectance).After downloading the imagery from USGS platform Standard procedure followed and applied for image processing such as Image Enhancement, Image Analysis window, Pre Processing, Band Composition, Exclusion of No value data and Stripping and Cloud coverage, De-spiking and histogram equalization, technique were used to make the image interpretable As Faisalabad is not available in single image so four images are required to attain the complete Administration body of the District. Each image preprocess than band composition. For the Urban sprawl and vegetation mapping useful combination which were used in all the three images are 5,4,2 and for the water visibility sometime bands switched to 7,4,2 these two-combination used to categorize the pixel for classification. Extraction of AOI (Area of Interest) using Extract by mask tool.

\section{Image Classification}

For image classification, after all afore-stated processes and preprocessing image readily available for the classification technique to be applied for this in case of supervised classification Training sites assigned as land cover classes such as Water, Breland, Built-up, Soil and other LULCs. To measure the land change three images were classified using Maximum likelihood technique using signature file for the selected training areas i.e. Water bodies $\rightarrow$ consists of rivers, lake, Streams etc., Built-up area $\rightarrow$ consists of Commercial, Residential, industrial, high and low built-up and developed area Noncommercial, Recreational (Parks) Vegetation $\rightarrow$ Agriculture Forest \& Crops, Bare soil $\rightarrow$ Shrubs, bushes, barren land.

In Human machine interactive classification Maximum likelihood user must be well aware of training sites that whether the assigned pixel belong to the specified class it will take time to compute overall image pixels one by one and create land cover classes In the present image has constituted into four 
INTERNATIONAL JOURNAL OF ACADEMIC RESEARCH IN BUSINESS AND SOCIAL SCIENCES Vol. 9, No. 4, April, 2019, E-ISSN: 2222-6990 C 2019 HRMARS

LULC type Water, vegetation, built-up \& Bare soil if there is some unclassified pixels which are not clear they required more attention and verification of that specific zone. A cluster is identified using cluster tool and signature file as an input gives categorized LULC map.

The workflow in some below-stated steps will be followed to accomplish Land cover assessment. All points briefly shown as follows:

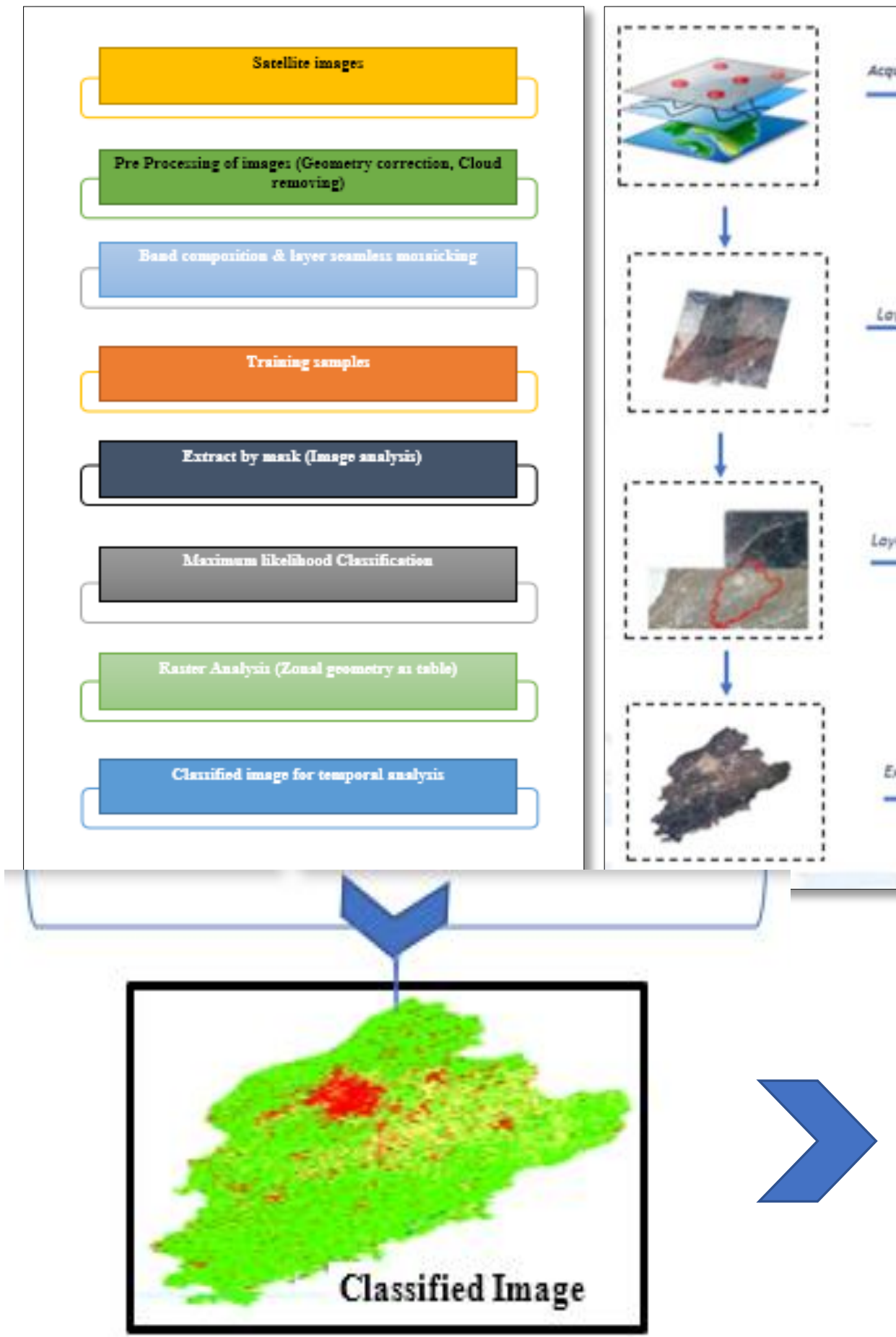

Acquitition of Landso? Dote Satrilite
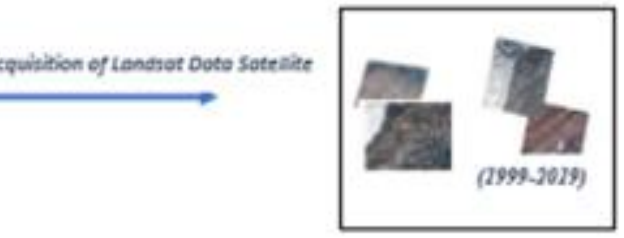

Sver Stockine

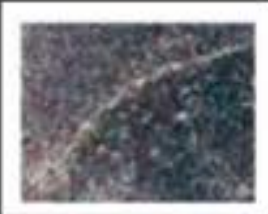

byer seomiest mosoicking
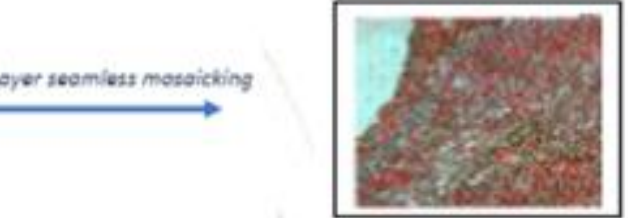

Extroct by mask ( $\mathrm{RO}$ i)
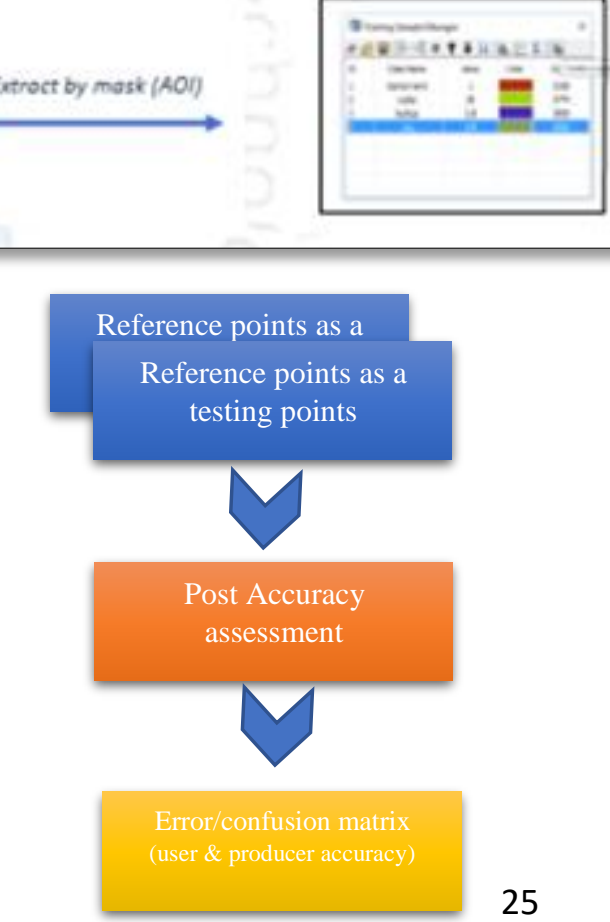
INTERNATIONAL JOURNAL OF ACADEMIC RESEARCH IN BUSINESS AND SOCIAL SCIENCES

Vol. 9, No. 4, April, 2019, E-ISSN: 2222-6990 @ 2019 HRMARS

\section{Post Classification Accuracy Assessment}

For three-decade analysis, three classified images for each decade equated quantitatively using Pivot table. For this purpose, Reference points are taken as aa Test Samples using base-map (ArcGIS online services $\rightarrow$ Online World imagery) as it is always not possible to visit the field class accuracy is assessed using test pixels corresponding spatially in the LULC categorized image. In picture-perfect biosphere, we would be able to field verified ground reference location but, in some scenarios, it is not imaginable in case of large area to visit each site user may select reference points. The test pixels should be consistently distributed across the image they should also be and must have to concise and unique from those pixels used as training sample while creating signature files. Error matrix is extensively adequate to assess the accuracy level.

Satellite interpretation contains some error whether user generated whether classified by the unsupervised classification in form of unclassified pixels or no value data the derived information whether by Human machine interactive classification vice versa the error source must be known to eradicate the error for this purpose error matrix plays a vital role. For each land cover 40 Reference points were taken and analyze converting the points to pixels and then using local combine tool combine the points with the classified image and then export the table in database (.dbf) format for further usage in the pivot tool as a value field. Following error matrix (1999-2010) indicate the accuracy level. Muhammad Farooq Hussain states that

"Kappa coefficient estimated the accurately classified pixel misclassified pixels".

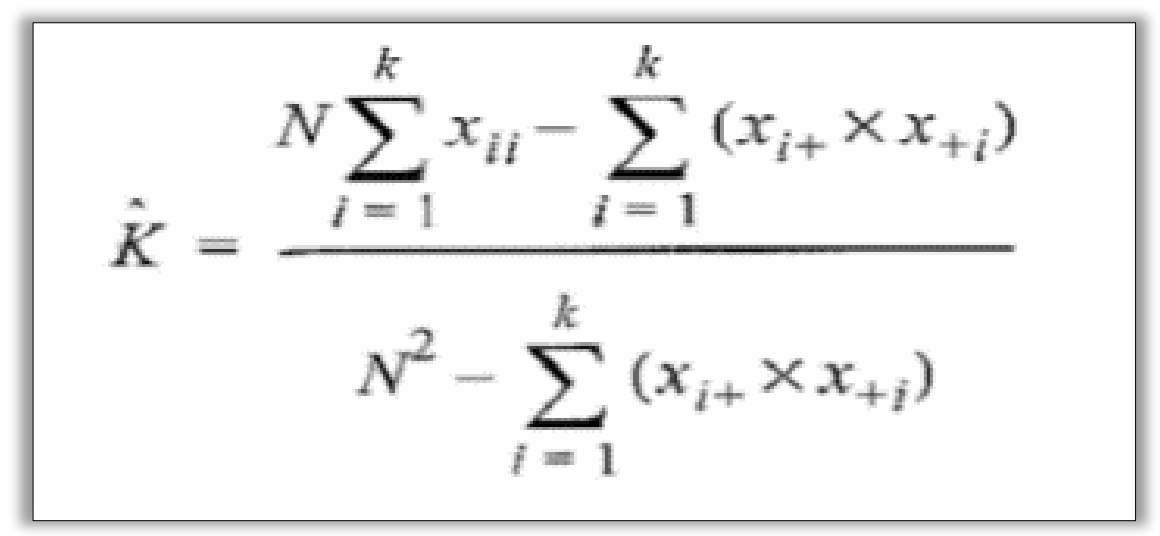

[Source: (Jensen, 2011]) 
INTERNATIONAL JOURNAL OF ACADEMIC RESEARCH IN BUSINESS AND SOCIAL SCIENCES Vol. 9, No. 4, April, 2019, E-ISSN: 2222-6990 @ 2019 HRMARS

\begin{tabular}{|c|c|c|c|c|c|}
\hline \multicolumn{7}{|c|}{ Accuracy Assessment (1999) } \\
\hline \multicolumn{7}{|c|}{ Class } \\
\hline Raster value & Water & Veg & Built-up & Bare land & Row Total \\
\hline 1 & 36 & 2 & 1 & 0 & 39 \\
\hline 2 & 2 & 38 & 0 & 0 & 40 \\
\hline 24 & 1 & 0 & 30 & 0 & 31 \\
\hline 30 & 1 & 0 & 9 & 40 & 50 \\
\hline Grand Total & 40 & 40 & 40 & 40 & 160 \\
\hline
\end{tabular}

\begin{tabular}{|c|c|c|}
\hline \multicolumn{2}{|c|}{ Table 3: Error Matrix 2010 } \\
\hline \multirow{2}{*}{ Land Type } & Producer's Accuracy & User's Accuracy \\
\hline Vegetation & 90 & 92.31 \\
\hline Bare land & 95 & 95 \\
\hline Water & 75 & 96.77 \\
\hline Built-up & 90 & 80.00 \\
\hline
\end{tabular}

Table 4: Overall Accuracy

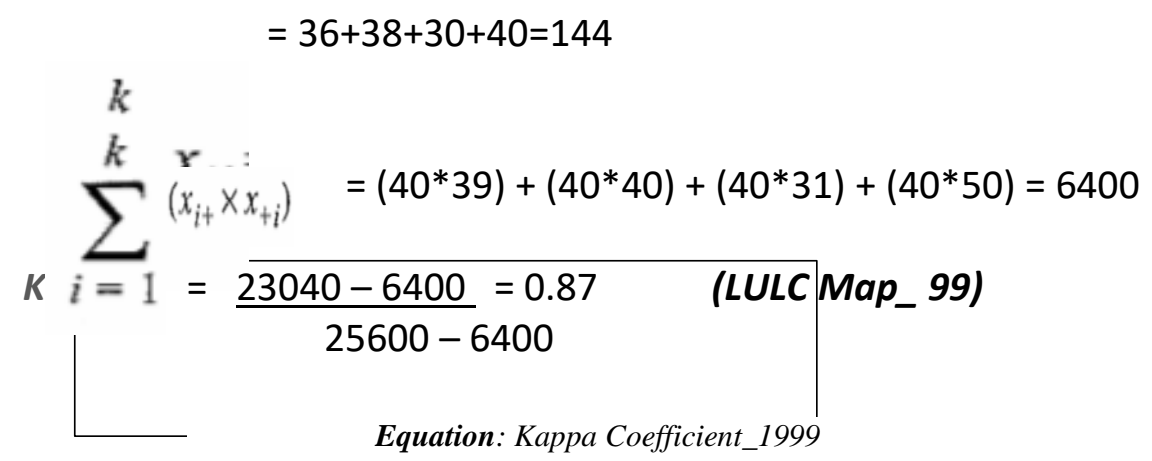

Accuracy Assessment (2010)

Class

\begin{tabular}{|c|c|c|c|c|c|}
\hline Raster value & Veg & Bare land & Water & Built-up & Row Total \\
\hline 1 & 39 & 4 & 0 & 2 & 45 \\
\hline
\end{tabular}


INTERNATIONAL JOURNAL OF ACADEMIC RESEARCH IN BUSINESS AND SOCIAL SCIENCES Vol. 9, No. 4, April, 2019, E-ISSN: 2222-6990 @ 2019 HRMARS

\begin{tabular}{|c|c|c|c|c|c|}
\hline 102 & 0 & 32 & 4 & 4 & 40 \\
\hline 322 & 0 & 0 & 34 & 1 & 35 \\
\hline 627 & 0 & 4 & 2 & 33 & 39 \\
\hline Grand Total & 40 & 40 & 40 & 40 & 160 \\
\hline
\end{tabular}

\begin{tabular}{|c|c|c|}
\hline Land type & Producer's Accuracy & User's Accuracy \\
\hline Veg & 97.5 & 86.67 \\
\hline Bare land & Table85: Error Matrix & 2010 \\
\hline Water & 85 & 80 \\
\hline Built-up & 82.5 & 97.14 \\
\hline \multicolumn{2}{|c|}{ Overall accuracy $=86.25 \%$} \\
\hline
\end{tabular}

Table 6: Overall Accuracy_2010

$=39+32+34+33=138$

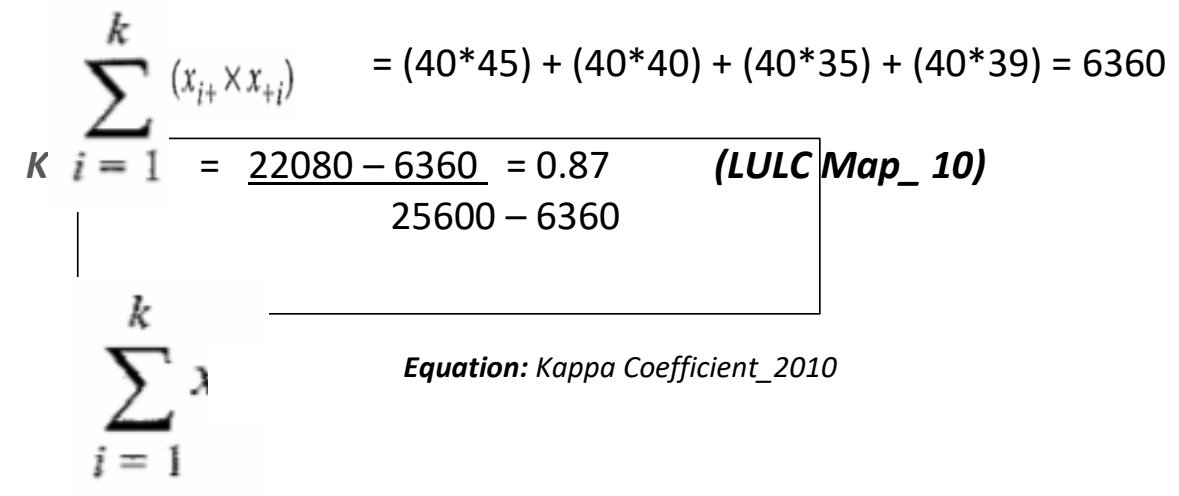


INTERNATIONAL JOURNAL OF ACADEMIC RESEARCH IN BUSINESS AND SOCIAL SCIENCES Vol. 9, No. 4, April, 2019, E-ISSN: 2222-6990 @ 2019 HRMARS

\begin{tabular}{|c|c|c|c|c|c|}
\hline \multicolumn{7}{|c|}{ Class } \\
\hline \multicolumn{7}{|c|}{ Accuracy Assessment (2019) } \\
\hline Raster value & Built-up & Bare land & Water & Veg & Row Total \\
\hline 117 & $\mathbf{3 6}$ & 6 & 1 & 0 & 43 \\
\hline 185 & 2 & $\mathbf{2 6}$ & 0 & 5 & 33 \\
\hline 260 & 0 & 0 & 38 & 0 & 38 \\
\hline 282 & 2 & 8 & 1 & $\mathbf{3 5}$ & 46 \\
\hline Grand Total & 40 & 40 & 40 & 40 & 160 \\
\hline
\end{tabular}

Table 7: Error Matrix_2019

\begin{tabular}{|c|c|c|}
\hline Land Type & Producer's Accuracy & User's Accuracy \\
\hline Vegetation & 90 & 83.72 \\
\hline Bare land & 65 & 78.79 \\
\hline Water & 95 & 100 \\
\hline Built-up & 87.5 & 76.09 \\
\hline \multicolumn{3}{|c|}{ Overall accuracy $\mathbf{8 4 . 3 7 \%}$} \\
\hline
\end{tabular}

Table 8: Overall Accuracy_2019

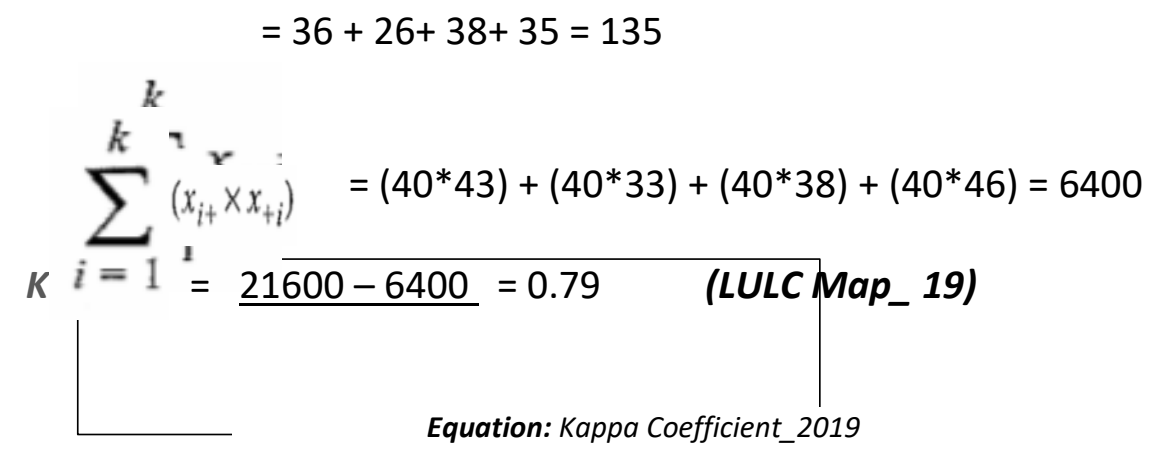

When the user knows the source of error that will help to analyze the data for future interpretations, policy implications and inferences. "Classified image Accuracy mapped by the total correct classified pixels by the total nth pixel".

Accuracy results analysis \& pictorial construal:

\begin{tabular}{|c|c|c|c|c|c|}
\hline Land type & $1999(\%)$ & $\mathbf{2 0 1 0}(\%)$ & $\mathbf{2 0 1 9}(\%)$ & $\begin{array}{c}\text { Change in Area } \\
\mathbf{1 9 9 9 - 2 0 1 0}(\%)\end{array}$ & $\begin{array}{c}\text { Change in Area } \\
\mathbf{2 0 1 0 - 2 0 1 9}(\%)\end{array}$ \\
\hline Water & 11.72 & 0.81 & 0.53 & -10.9118 & -0.28 \\
\hline
\end{tabular}


INTERNATIONAL JOURNAL OF ACADEMIC RESEARCH IN BUSINESS AND SOCIAL SCIENCES

Vol. 9, No. 4, April, 2019, E-ISSN: 2222-6990 @ 2019 HRMARS

\begin{tabular}{|c|c|c|c|c|c|}
\hline Vegetation & 50 & 81.32 & 75.31 & 31.52 & -6.01 \\
\hline Built-up & 5.38 & 9.41 & 10 & 4.04 & 0.35 \\
\hline Bare land & 33.24 & 8.46 & 14.4 & -24.79 & 5.94 \\
\hline
\end{tabular}

Multi-Temporal Analysis (LULC Maps, Clustered column Line, Area graph, Pie Charts)

Table 9: Change proportion
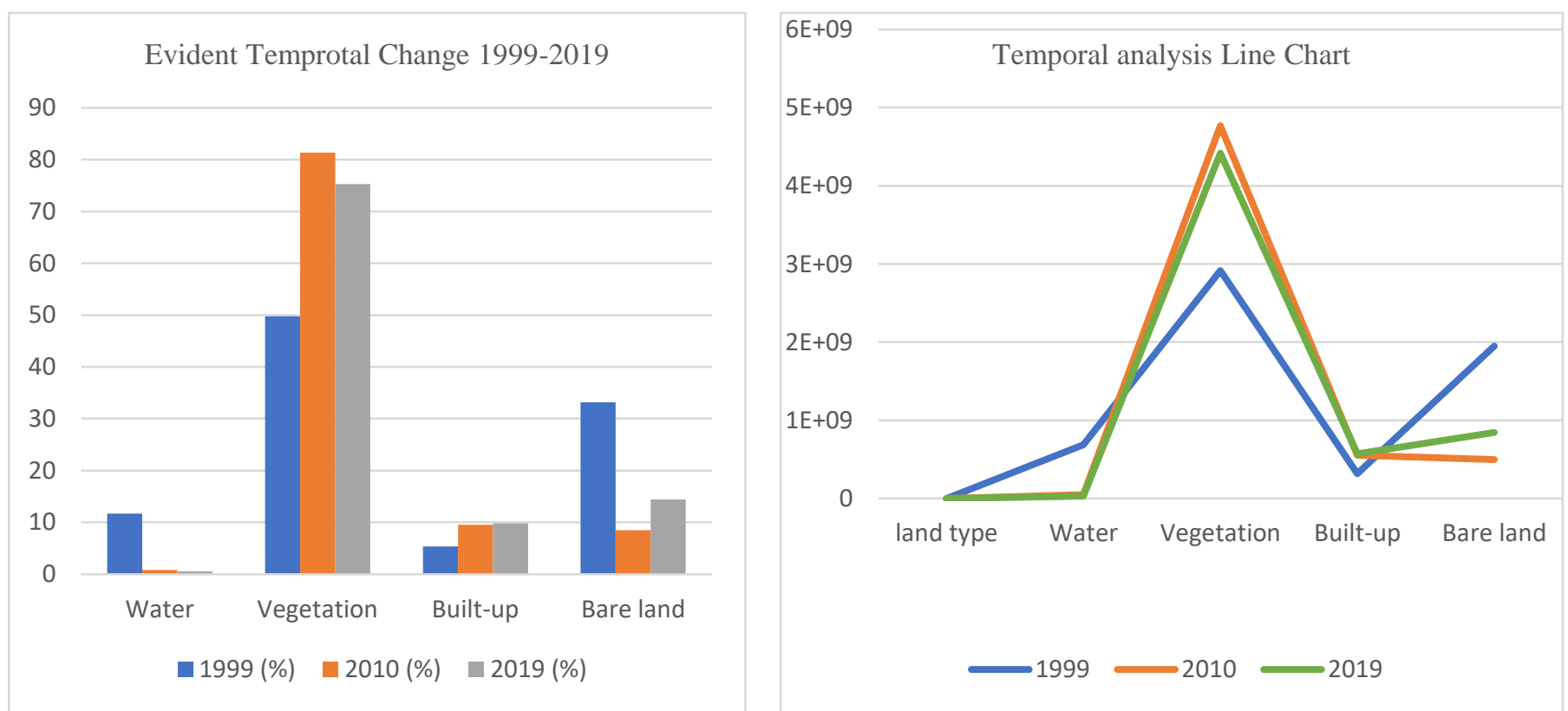

Area-graph 1999-2019 
INTERNATIONAL JOURNAL OF ACADEMIC RESEARCH IN BUSINESS AND SOCIAL SCIENCES Vol. 9, No. 4, April, 2019, E-ISSN: 2222-6990 @ 2019 HRMARS
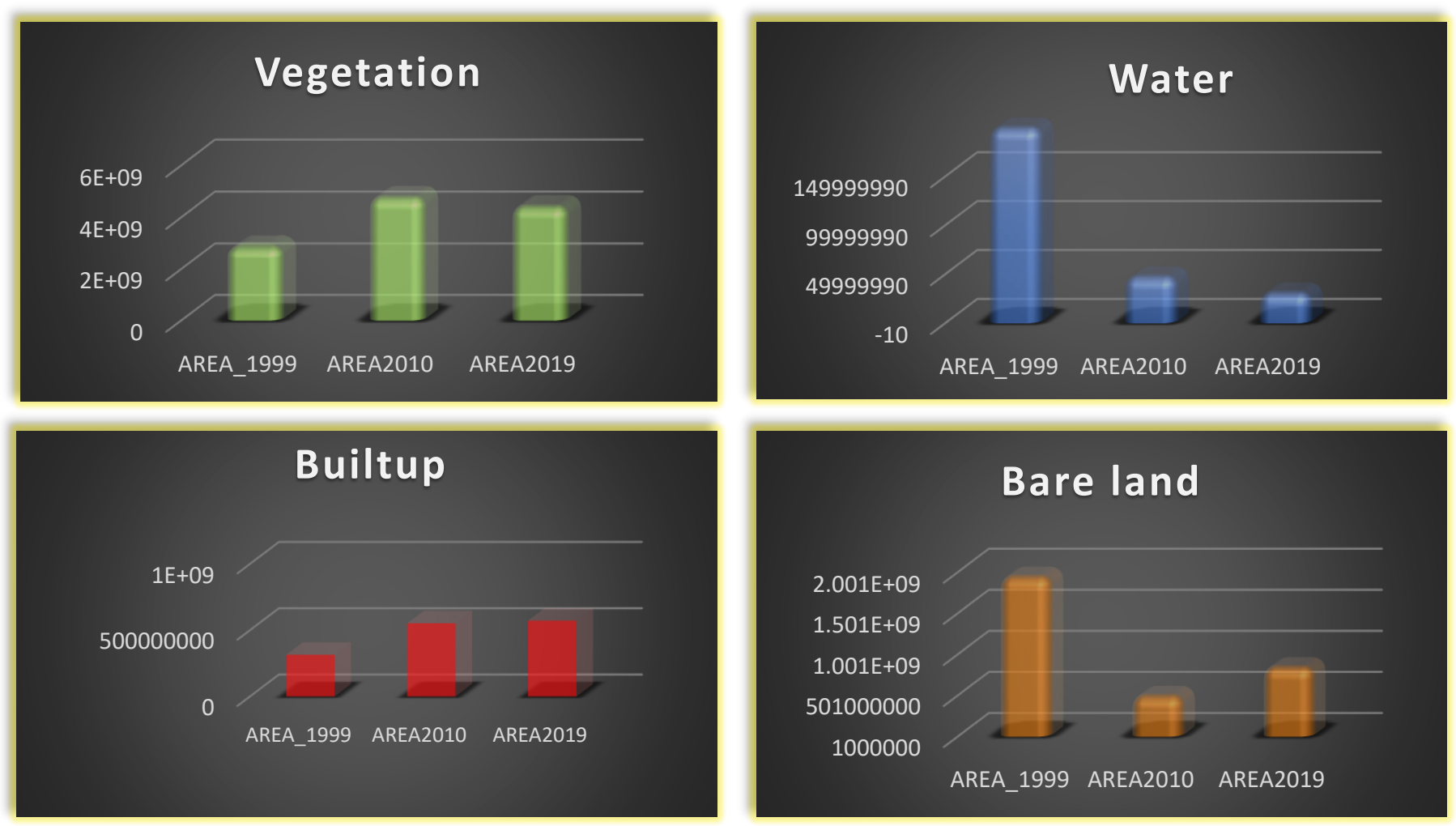

1999-2019 graphical representation

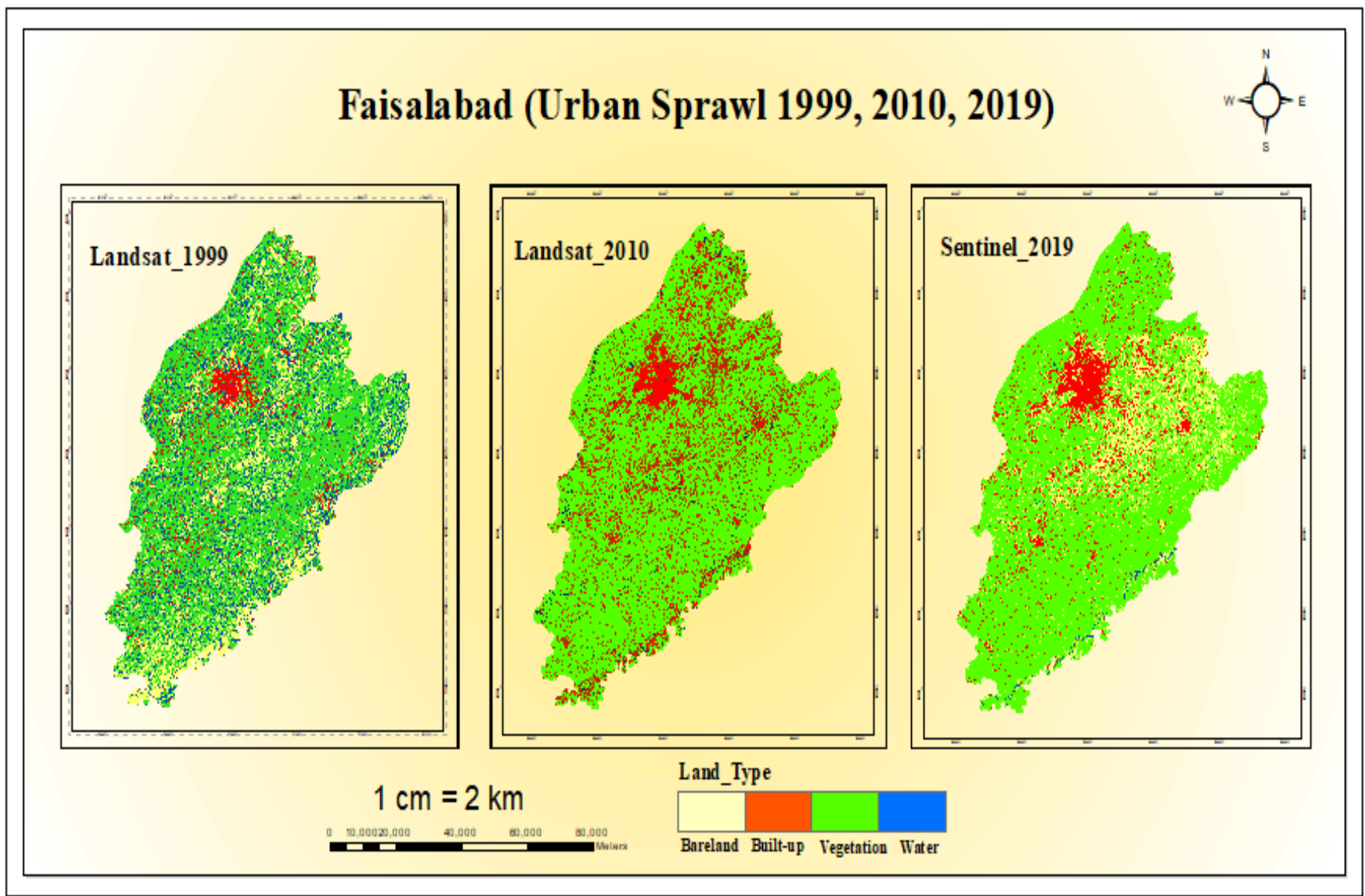

Temporal Analysis 1999-2019 
INTERNATIONAL JOURNAL OF ACADEMIC RESEARCH IN BUSINESS AND SOCIAL SCIENCES

Vol. 9, No. 4, April, 2019, E-ISSN: 2222-6990 @ 2019 HRMARS
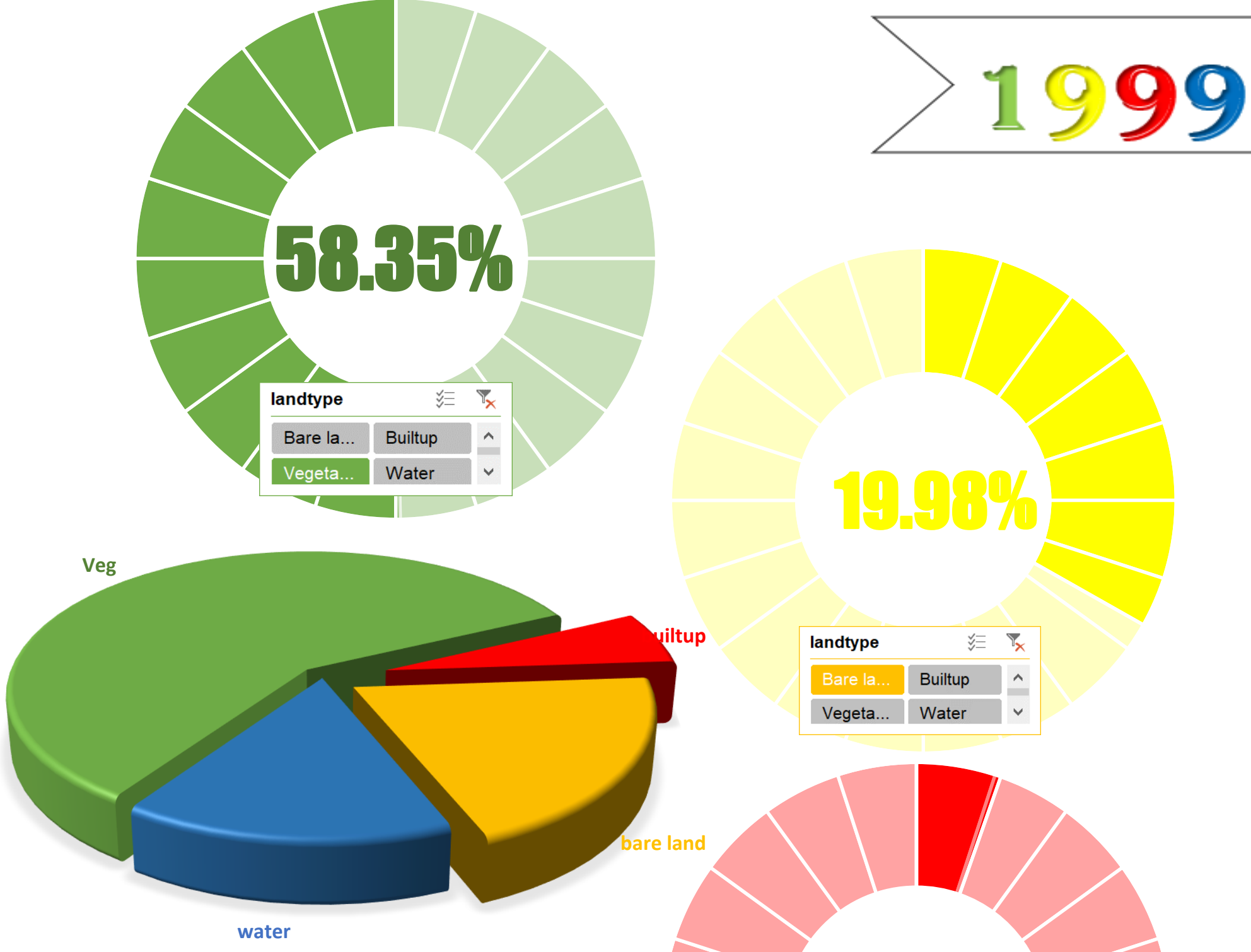

\begin{tabular}{|c|c|c|}
\hline landtype & & \\
\hline Bare la.. & Builtup & \\
\hline Vegeta & Water & \\
\hline
\end{tabular}

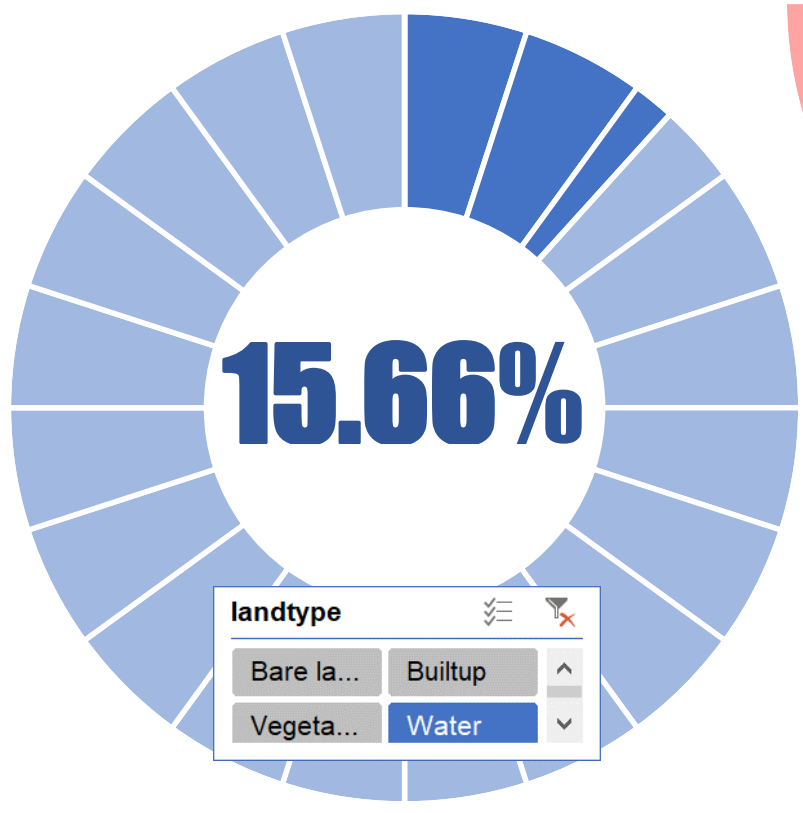


INTERNATIONAL JOURNAL OF ACADEMIC RESEARCH IN BUSINESS AND SOCIAL SCIENCES

Vol. 9, No. 4, April, 2019, E-ISSN: 2222-6990 @ 2019 HRMARS
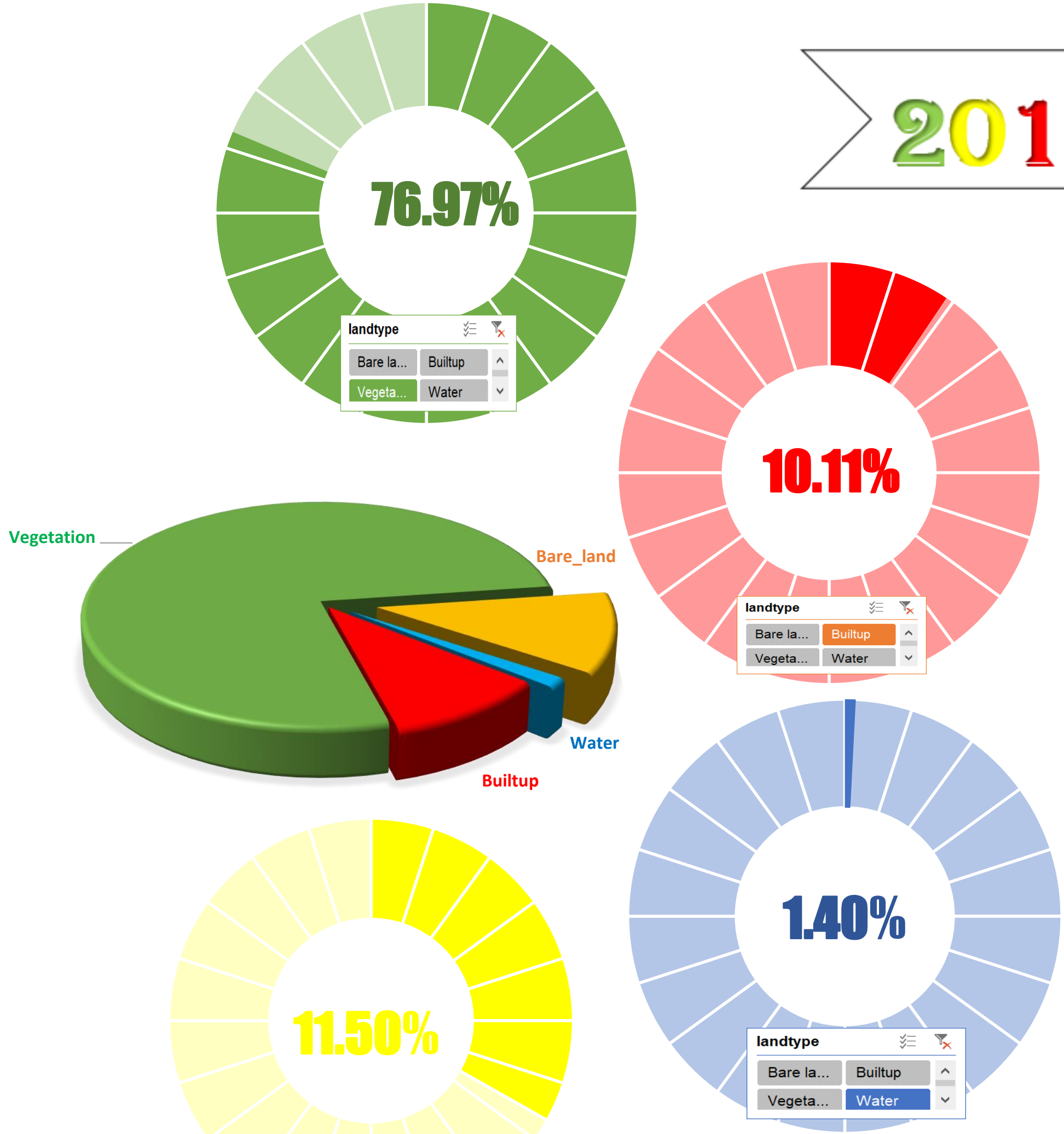

\begin{tabular}{|c|c|c|}
\hline landtype & & $\nabla_{x}$ \\
\hline Bare la.. & Builtup & ^ \\
\hline Vegeta.. & Water & $\checkmark$ \\
\hline
\end{tabular}


INTERNATIONAL JOURNAL OF ACADEMIC RESEARCH IN BUSINESS AND SOCIAL SCIENCES

Vol. 9, No. 4, April, 2019, E-ISSN: 2222-6990 @ 2019 HRMARS
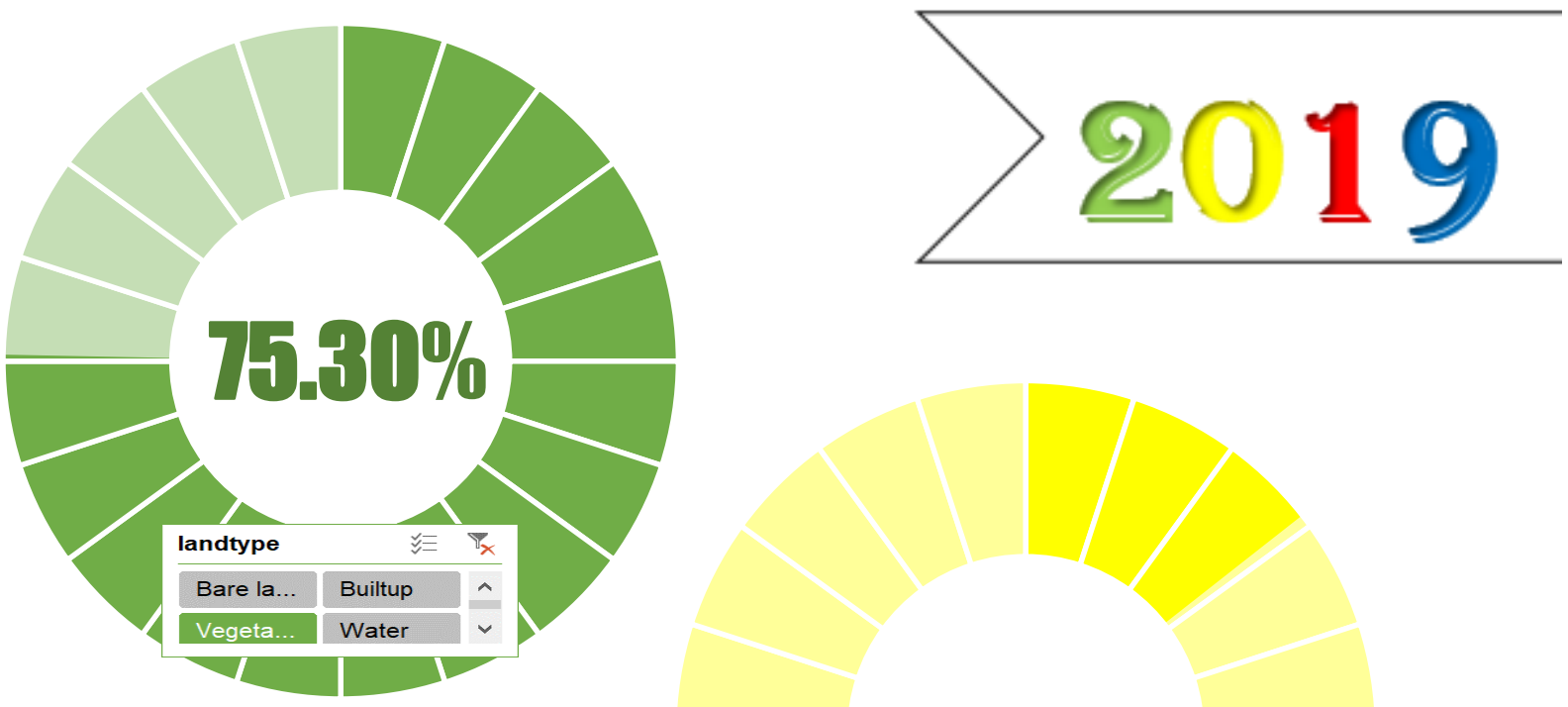

\section{Vegetation}
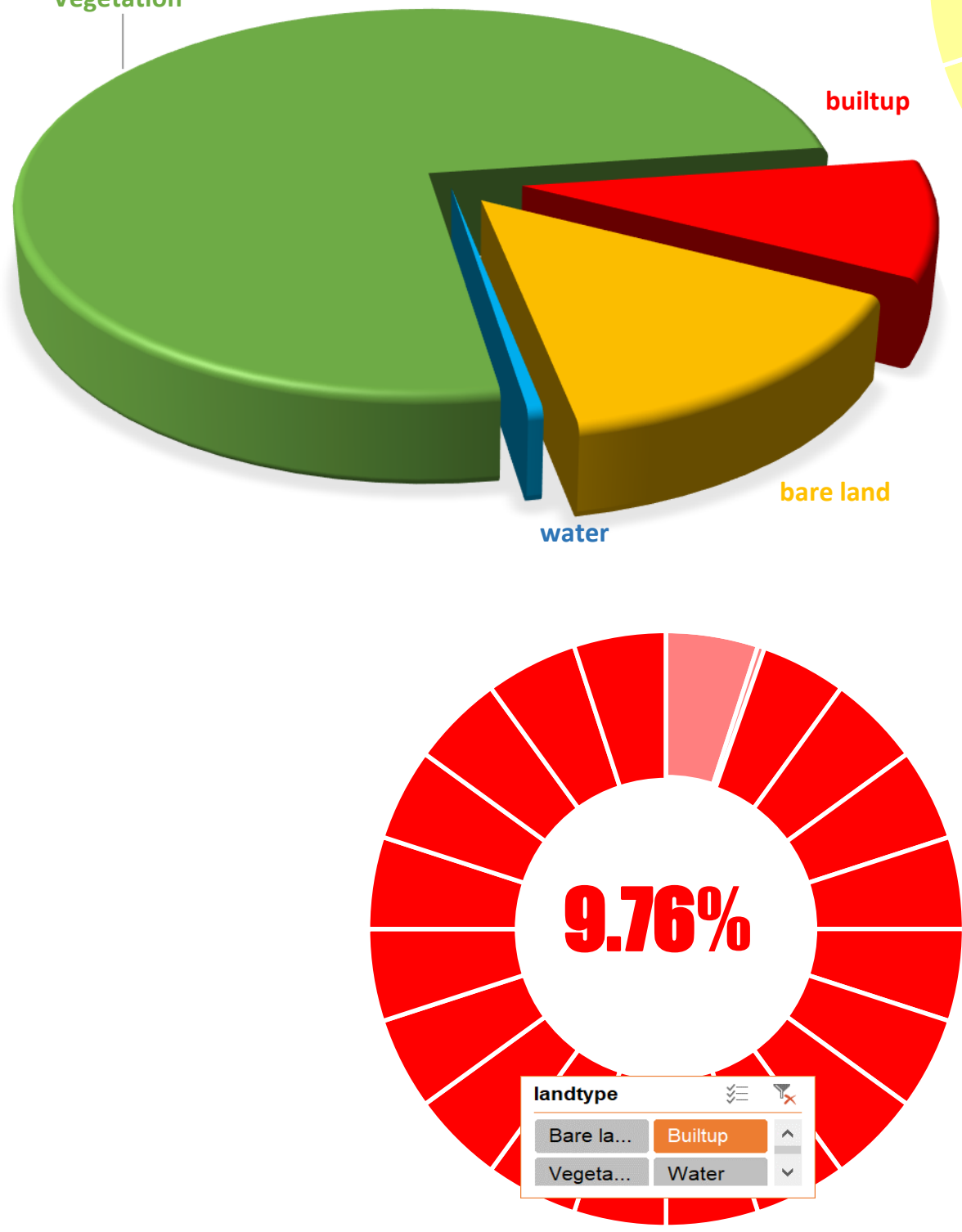


\section{Conclusion}

The study illustrates ration and appraises urbanization in Faisalabad along the environs, via RSGIS practices. There is a significant conversion of land in the last 30 years. The quantified maps analyzed as an outcome temporal land transformation computed. LULC influences determined. The improvement in lifestyle education and other service facilities, the change effect on natural resources directly, i.e., vegetation, water, agricultural land. The urban land directly leads to the loss of agricultural and barren land increased development and industrialization in Faisalabad are the major and foremost reason for dispersing land loss without any planning and policy and monitoring mechanism.

Supervised classification which is extensively adequate and acceptable Maximum likelihood classification and with the help of pivot Tables and charts LULC analysis inferred. The spatial expansion clearly depicted in Map. Major vegetation loss dictates the transformation of the Land cover just in past few decades. The change matrix indicated the change in cultivation pattern. The Table 4 illustrates the transition matrix (1999-2019). The human interactive technique produced better results than unsupervised classification as more chances of unclassified and no data values in the classified image. One of most major hurdles confronted is that Faisalabad is a large District and consist of four images so image preprocessing is tiring task to make the image accurate for analysis and in Landsat data image without strips and cloud-free imagery is rarely available so all the process consumes time before the actual analysis. Thus, the post accuracy assessment indicates the level of accuracy of classification that which pixel belongs to which land type exactly. So, sightseeing deceits how effectually the urban evolution is strategizing, governed and administered with less hindering to agro-rural system. The most evident observed perspective is mostly landscape change lead by human intrusion and built-up dominates the agricultural, vegetative and barren land. Faisalabad being acquainted and recognized as an industrial zone but the industrialization and the residential development root cause of the conversion of landscape

This will judiciously reveal geo-system implication and deployment in anywhere whether in Faisalabad or any other populated city of Pakistan. There must be some plan for the management of such sprawl and use of land whether long term or short term. Wisdom lies how to utilize the blessed natural resources.

\section{References}

Ghaffar, A. \& Shirazi, S. A., M. (2012). Change Detection Analysis of Land Use By Using Geospatial Techniques: A Case Study Of Faisalabad-Pakistan. 24. 539-546.

World population projected to reach 9.6 billion by 2050. (3 2013, New York, June 3). Retrieved from United Nations, Department of Economic and Social Affairs:

http://www.un.org/en/development/desa/news/population/un-report-world-populationprojected-to-reach-9-6-billion-by-2050.html

UN. (2018). New York: United Nations, Department of Economic and Social Affairs.

Roser, H. R. (2018). Urbanization, Retrieved from 'https: //ourworldindata.org/urbanization'.

Smith, D. A., Casa, U. (United Nations 2018). World City Populations 1950-2035. http://luminocity3d.org/WorldCity/\#2/59.0/19.7: D A Smith CASA, UCL. 
Gumma, M. K., Irshad, M., Nedumaran, S., Whitbread, A., Lagerkvist, C. J. (2017). Urban Sprawl and Adverse Impacts on Agricultural Land: A Case Study on Hyderabad, India. Remote sensing. 16p. Doi: $10.3390 /$ rs9111136 https://hdl.handle.net/10568/89567

Hussain, M. F. (2018), Research Gate, https://www.researchgate.net/post/what_is_ Kappa Coefficient

Adusei, K. (2014). Land Cover Change in a Savanna Environment. A Case Study of Bawku Municipal. (Electronic Thesis or Dissertation). Retrieved from https://etd.ohiolink.edu/

Bhalli, M. (2011). A GIS Based Analysis of spatial patterns of urban Growth in Faisalabad city 19812010. Faislabad, Pakistan. 